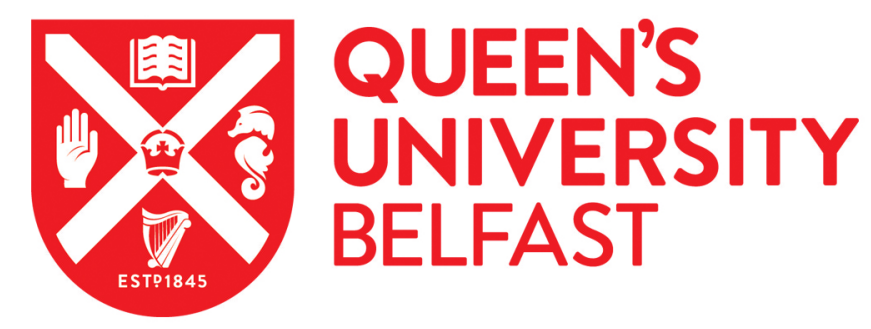

\title{
Changes in the Narratives of Europeanization: Reviewing the Impact of the Union before the Crisis
}

Agarin, T. (2017). Changes in the Narratives of Europeanization: Reviewing the Impact of the Union before the Crisis. Sudosteuropa, 65(1), 1-9. https://doi.org/10.1515/soeu-2017-0001

\author{
Published in: \\ Sudosteuropa
}

Document Version:

Publisher's PDF, also known as Version of record

Queen's University Belfast - Research Portal:

Link to publication record in Queen's University Belfast Research Portal

\section{Publisher rights}

(C) 2017 Walter de Gruyter $\mathrm{GmbH}$. This work is made available online in accordance with the publisher's policies. Please refer to any applicable terms of use of the publisher.

\section{General rights}

Copyright for the publications made accessible via the Queen's University Belfast Research Portal is retained by the author(s) and / or other copyright owners and it is a condition of accessing these publications that users recognise and abide by the legal requirements associated with these rights.

Take down policy

The Research Portal is Queen's institutional repository that provides access to Queen's research output. Every effort has been made to ensure that content in the Research Portal does not infringe any person's rights, or applicable UK laws. If you discover content in the Research Portal that you believe breaches copyright or violates any law, please contact openaccess@qub.ac.uk. 


\section{Changes in the Narratives of Europeanization. Reviewing the Impact of the Union before the Crisis}

The original idea for this special issue of Südosteuropa was mooted back in the summer of 2014, when the first fissures began to appear in the approach of the European Union (EU) towards its candidate countries in the Balkans. Over the time we have been soliciting, then working on the papers and going through the revision process, many events took place in the EU, its candidate countries, and in the neighbourhood. The political crisis in Ukraine has turned into fullscale civil war; anxieties over the prospect of entry into the European Union have given space to pessimism about the general prospects of the once indivisible EU; talk of new rounds of accession has gradually become more and more muted. Also, the referendum on the UK's membership in the EU has raised the spectre of other member-states turning their backs on the EU's closer geopolitical and economic integration. And, most recently, the foiled coup d'état in Turkey has been taken as a mandate for a top-down reshaping of domestic institutions in that country, with consequences that remain uncertain. All these political developments question

\section{GUEST EDITOR}

\section{Timofey Agarin}

is Lecturer in Politics and Ethnic Conflict at the School of History, Anthropology, Philosophy and Politics, Queen's University Belfast. the role and indeed the ability of the EU to bring about change in its member, candidate, and neighbouring states that would meet the expectations of these countries' citizenries. What is more, these changes in the political dynamics across the wider Europe urge us to rethink our expectations of the Europeanization process, about its implications for its member and candidate states, and not least about the very basis of the normative framework undergirding the EU.

Two years ago, my fellow authors and I were already pessimistic about the timeline for the Western Balkan states' accession to the EU. At that time, JeanClaude Juncker had just spelt out that there would be no further enlargement during his term as the head of the EU Commission, and it seemed to many of our critics that we were simply toeing the line of European bureaucrats too 
closely. Today it is clear that although EU membership is but a distant goal on the political horizons of many candidate states, the EU has lost much of its appetite to embrace new members. Now more than ever is it important that we revisit our understandings of Europeanization beyond a narrow understanding of it as a one-way ticket to Brussels. Indeed, the 'carrot and stick' approach has since yielded to bickering over policy priorities in the EU and its candidate countries. Because of domestic challenges in the founding member-states, national politicians now focus on the priorities of their domestic populations and stick to merely superficial commitments to the promotion of democracy, the rule of law, and freedoms in candidate states. The United Kingdom's June 2016 referendum vote to leave the European Union further indicates the challenging nature of the underlying parameters affecting the EU's relationships with its members and with candidate countries.

The recent changes in the narrative of Europeanization and the EU's own dwindling role in those states seeking EU membership point to the limits of our past understandings about the nature of the Europeanization process. And what a process it is: the earlier waves of EU enlargement have largely been seen as outcomes of the democratization of states, market liberalization, and a growing respect for the diversity of opinions, identities, and expectations among the newly accepted nations' domestic populations. In effect, much of the talk about the EU being in free fall after the Brexit vote points directly to issues dealt with by all the papers in this special issue: What does it mean to engage with the notion of Europeanization when its pivotal agent is becoming fuzzier by the day? All the contributions, therefore, are not so much about countries, policies, and changes therein 'as such'; rather, they are fundamentally about previous ways of thinking about Europe as a crisis-free area and thus also a cogent magnet for positive political change. While this view has been omnipresent in previous work on the EU's impact on candidate countries and in the neighbourhood, a contemporary set of home-grown challenges calls for a fundamental revision of the object of such research. With so many crises exposing the EU's lack of a unified voice and, consequently, a common stance on matters ranging from financial regulation, economic redistribution, and refugee accommodation to the situations in individual countries including Greece, Ukraine, and the UK, it appears that the issue of EU-building as a state-building project is the central problem.

The final revisions to the texts in this issue came in just days after the foiled coup d'état in Turkey, an event which underlined the impact that Europeanization narratives exert beyond Europe's borders. Studies focusing on Europe's impact on Turkey have been grappling with many concerns since the country was accepted as a candidate state; some have identified the change in the discussion's semantics, while others have homed in on conceptual change. But even 
before the question of the rule of law and democratic governance in Turkey grabbed the headlines, events across the Western Balkans set a big question mark over the assumption that the Europeanization process had been the guarantor of peace, stability, growth, and the consolidation of democracy in the region. The rise of populism and of identitarian movements across all member-states in the wake of the financial crisis of 2007, the cracks in solidarity between donor and receiver member-states following the Greek crisis, and concerns about the potential impact on refugee integration after 2015 came as a wake-up call for many pro-European evangelists: Can we still think that the European Union, in the shape that we now know it, is to be with us forever? Is it even legitimate to superimpose on candidate states not just a vague definition of Europe, but one which has become even more fractured, especially when many of the EU's very fundamentals have now been called into question? As our issue was getting more exciting by the minute, its authors and I were happy to go back to basics and tackle many of these scholarly challenges in this remarkable political climate.

Given this context, in early August 2016 this journal's editor and I asked the authors to address some of the concerns about the future of Europeanization that scholars and publics are likely to talk about in the near future. Some of these questions' answers allowed us to pull together the different threads in the narratives of Europeanization found throughout the papers and align these with the challenges that Europeanization research will be facing in the medium term.

We invite you, the reader, to see the papers collected in this special issue in the context of the Dossier published in volume 64, issue 3 of Südosteuropa (2016). Its contributions query the prospect of the $\mathrm{EU}$ and its capacity to effect change in the Western Balkans. Erhard Busek, the former special coordinator for the Stability Pact, pleads that we not forfeit all that has been achieved in the region despite the circumstances of contemporary uncertainty; John Breuilly discusses the case of the UK leaving the EU and its impact on the potential re-emergence of affection for the nation-state across the continent and beyond; and, in a debate among historians of Southeastern Europe, we find incisive (though, we hope, inaccurate) assessments of the EU's prospective turn away from joint agendas and common action plans among its member-states, despite their citizens' expressed wish for greater cooperation on individual policies. In fact, indirectly these and many previous contributions published in Südosteuropa on single-case and issue studies underline that before seriously discussing the prospects of accession, European institutions want to see nation-states across the region in a form that is unpalatable for domestic publics and political entrepreneurs alike. To join 'Europe', Western Balkan states are expected to undertake greater, not less, state-building: a process that would require considerable domestic changes in polities, politics, and politicking. 
To some degree, the perception of European meddling in the domestic affairs of 'national homesteads' in the candidate states also reflects the current nescience of Eurosceptics. Thus it seems that Brexit and the range of other European crises are all part of the same story about the changing narratives of Europeanization: Soeren Keil, alone and in collaboration, has been writing tirelessly about the EU's role in state-building across the Western Balkan region; similarly, Florian Bieber's Routledge (formerly Ashgate) book series on Southeastern Europe has repeatedly drawn attention to deficits in commitments to effective governance across the region. ${ }^{1}$ My own past work on Central Eastern EU member-states illustrates vividly that many a sensitive issue, such as minority protection for example, has been used to conserve rather than consolidate existing political regimes before as well as after the 2004 enlargement. ${ }^{2}$ This special issue's authors contend that different aspects of state-building have been the focus of the Europeanization process across the region, and while this process has been running in parallel to nation-state building, much of the scholarship to date has neglected the adverse effects of crafting democratic states as nation-states. One of the prominent effects of this process is what Erin Jenne and Florian Bieber refer to as 'building subversive institutions'. ${ }^{3}$ This has meant that states have been withdrawing the provision of services to their citizens, becoming less 'deep' 4 and resembling the 'night watchman state' ever more. At the same time, Western Balkans states have outsourced the delivery of many social services to non-state actors such as nongovernmental organizations (NGOs) and other international organisations, absolving themselves from fulfilling numerous obligations and duties to their citizens. ${ }^{5}$ These processes have been extensively studied in the member-states which joined in the 2004 and 2007 waves of enlargement, both

${ }^{1}$ Soeren Keil, Multinational Federalism in Bosnia and Herzegovina, Farnham 2013.

2 Timofey Agarin / Karl Cordell, Minority Rights and Minority Protection in Europe, London 2016; Timofey Agarin, The Dead Weight of the Past? Institutional Change, Policy Dynamics and the Communist Legacy in Minority Protection, in: Karl Cordell / Timofey Agarin / Alexander Osipov, eds, Institutional Legacies of Communism. Change and Continuities in Minority Protection, London 2013, 14-30.

${ }^{3}$ Erin K. Jenne / Florian Bieber, Situational Nationalism. Nation-Building in the Balkans, Subversive Institutions and the Montenegrin Paradox, Ethnopolitics 13, no. 5 (2014), 431-460, DOI: 10.1080/17449057.2014.912447.

4 Solveig Richter, Two at One Blow? The EU and Its Quest for Security and Democracy by Political Conditionality in the Western Balkans, Democratization 19, no. 3 (2012), 507-534, DOI: 10.1080/13510347.2012.674360.

${ }^{5}$ Beate Sissenich, Weak States, Weak Societies. Europe's East-West Gap, Acta Politica 45, no. 1 (2010), 11-40, DOI: 10.1057/ap.2009.28. 
in terms of a 'neoliberal turn' in policymaking ${ }^{6}$ and with regard to the creation of weak states. ${ }^{7}$

In her essay, Nevena Nancheva brings us directly to the core of dealing with the challenging narrative of Europeanization and calls on scholars to rethink the study of Europeanization in relation to the issue of minorities. She speaks about 'visions' of sovereignty, nationalism, human rights, and their connection to security issues as related to the 'normative power of Europeanization'. Whereas in her account the structure of 'European international society' is pivotal for the effectiveness of transnational regimes, her suggestion is to tackle-and move beyond - nation-state structures by putting policies into place that are common for all EU member-states. However, as the EU has lately gone backwards in this respect she links her reflections on security contexts to both the refugee crisis (especially as regards the 'Balkan route') and the escalated political uncertainty in Macedonia. Nancheva's paper gets straight to the point about the lack of commitment by international and national actors alike to Europeanization per se: what we see instead is a mismatch between what the EU can do and what is actually communicated to people on the ground in the states affected. We well know that the EU can change domestic policies only if domestic institutions and actors are willing to accept such changes; Nancheva excellently maps the types of actorness and, indeed, the rationales of the actors that are acting on behalf of tentative 'Europe' in the domestic arena.

Michael Potter, on the other hand, writes about the 'inconclusive' European involvement in Kosovo. In discussing the issue of accession, he has identified several stumbling blocks: the visions of a 'Greater Albania', the implied regional security threat that emerged out of nation-state building for Kosovo Albanians, and the complex entanglement of political entrepreneurs in the nationalizing project for Kosovo. While he takes on board the EU's commitment to the multiethnic character of the new state, where minorities have their rightful-and respected - place, his account of fleeting commitments to non-Albanian versions of political processes, narratives of statehood, and, crucially, participation in societal processes paints a dismal picture. Precisely these links implied in the Kosovar narrative of state-building are prone to abuse by self-serving political entrepreneurs and by those interpreting the Kosovar nation-building project as a long-deserved process of the state's nationalization as a part of Europeanization. These conclusions might not be palpable for Kosovo Albanians, nor Kosovo

${ }^{6}$ Rachel A. Epstein, In Pursuit of Liberalism. International Institutions in Postcommunist Europe, Baltimore 2008.

7 Heiko Pleines, Weakness as Precondition of Smooth Integration? Representation Strategies of Functional Interest Groups from New Member States at the EU Level, Journal of European Integration 33, no. 4 (2011), 507-521, DOI: 10.1080/07036337.2011.582286; Wim van Meurs, ed, Prospects and Risks Beyond EU Enlargement: Southeastern Europe. Weak States and Strong International Support, Opladen 2013. 
Serbs, nor indeed for many Kosovars committed to building an effective state for all residents of the county. As such, Potter's paper indicates a significant blind spot within past research: There is indeed a dearth of work on the depth of acquiescence to nation-building in Kosovo and its impact on the exclusion of minority (not only ethnic minority) voices. Those willing to engage with Potter's argument in depth are invited to consult his data-rich and insightful account of the descriptive representation of minority and micro-minority groups in Kosovo, which he provides in his doctoral work. To drill down to where his argument sits most uncomfortably with Europeanization and state-building narratives in Kosovo, the critical reader should be familiar with the enduring discourses of the adverse impacts of Europeanization on Kosovar state-building as found in the country's daily press.

Anastasiia Kudlenko is concerned with Bosnia, another post-conflict state, and how security issues form a part of the crisis management approach to state-building by European actors. Her account of short-term as well as more 'sustainable' measures to ensure stability in the country are all tightly linked to the promise of EU membership and how it has remained an elusive goal for some time. Kudlenko has accurately identified the lack of a robust state as one of the major sources of instability in the country, and while her paper looks at only one state, this issue is omnipresent across the Western Balkan region. Here the EU has had to engage in state-building directly, and while there is now a profusion of 'unfinished states' (such as Macedonia, Kosovo, Bosnia), this incomplete success is likely to become the main source of concern when thinking of international involvement to craft states elsewhere. The question is more potent today, as the likelihood of the 'core' European states losing interest in the 'periphery' may well only contribute to the growing fragility of the entire European security architecture. This - if any further evidence is needed - shows that European actors' lack of credible commitment to state-building for all affected residents says more about the futile nature of state-building by external actors per se than about progress in the case of Bosnia. Where reform receives no buy-in from domestic publics, as she demonstrates via the example of security sector reforms, her conclusions will remain accurate: issues larger than institution building are being sidelined for the sake of dealing with uncontentious reforms.

Niké Wentholt addresses the image of 'Europe' inside Europe itself, and how it is being projected onto the Western Balkans. She shows the strength of EU policy concerning the extradition of war criminals, while at the same time pointing out the mismatch between expectations and the reality on the ground. Wentholt is thoughtful in her assessment that it is the crumbling self-perception of the International Criminal Tribunal for the former Yugoslavia (ICTY) that shows partisanship. In fact, a toothless institution that neglects rights and concerns 
in its constituent countries can hardly be expected to constrain others' unruly behaviours. For the ICTY to be a success, as the paper suggests, the EU would need to accept the Western Balkan states as members and close the chapter on the 'Balkanization' of the region once and for all. Failing as it is to do this, the international community will continue to neglect the humanitarian catastrophe unfolding in Syria, where events in Aleppo are as dreadful as those we saw in Sarajevo some twenty years ago. There is no need to travel outside the EU to check the veracity of her argument, and though it is tempting to draw on the recent crisis affecting EU member-states' own consistency in its commitments, her analysis draws up a murky balance sheet of the international organisation's inability either to coordinate its members' views or to speak with a united voice to outsiders.

This argument is also picked up in the text co-authored by Laura Wise and myself. We discuss how the smooth image of 'stable political institutions' that facilitate the running of democratic polities elsewhere is being challenged by actors on the ground. Kosovo seems to fulfil all the formal prerequisites of a democratic state, yet its 'hardware' has not been in tune with the 'software' of politicking that one would expect with a smooth (i.e., linear) democratization towards a more European-style politics. The very prerequisites that the EU is supposed to bring as a package, such as political stability, a market economy, interethnic respect, and peace, have all somehow been stamped 'invalid' as a result of electoral bickering in Kosovo. And this predicament challenges so many of the existing parameters of what the scholarship has termed 'Europeanization'. Our paper therefore concludes that prospects for the future impacts of Europeanization would need to account for not only the projections of ideals in politics and politicking, but also the salience of real political institutions installed for the use of potentially unconsolidated democratic publics, who are willing and ready to abuse contentious issues to achieve their narrowly defined political goals.

Anna-Lena Hoh shows in her article that even though census-taking is one of the EU's conditions for accession, the EU has underestimated the effects of a population count. Although not requested by the EU, all Western Balkan countries have included data on ethnicity, language, and religion in their censuses. However, as both the enjoyment of rights and the access to political institutions by the citizens of Western Balkan states are often dependent upon their proportion in societies, census data on ethnocultural characteristics have become a highly volatile issue for politicking. In some cases, the collection of ethnocultural data has led to a politicization of the census as such: In Bosnia publication of the census results was severely delayed, and in Macedonia the data collection itself was aborted. In Croatia, another case discussed by Hoh, we see a strong alignment of ethnic, cultural, and religious identities in the mindsets 
of census-takers, attributable to the ongoing, albeit contentious, state-building endeavours for the majority undertaken by the Croatian ethnopolitical elites.

In the final contribution, Gözde Yilmaz and I discuss the career of the Europeanization discourse by focusing on the use of the concept in past research. The paper makes us somewhat pessimistic about the heuristic value added by (some strands of) Europeanization research, largely because the scholarship has been extremely effective in focusing on the outcomes, rather than the processes, of Europeanization. We believe that Europeanization's popularity as an analytical point of reference has resulted from a lack of epistemic clarity about how Europeanization works; some scholars have effectively capitalized on an ontological fuzziness about what Europeanization is. Despite the overall pessimism in our assessment of this scholarship, we believe that more can be gained from an understanding of Europeanization as a peer-to-peer learning dynamic, as well as by a disengagement from overtly normative accounts of Europeanization's unidirectional impacts on member, candidate, and neighbourhood states. As the Europeanization scholarship has incisively shown, all states wanting to join the EU must demonstrate beyond a reasonable doubt that they have been 'learning from the West'. Thus, the process of Europeanization, as well as the ensuing scholarship on its outcomes, treats candidate countries as 'takers' rather than as active 'shapers' of their own institutional transformations, making candidate states' 'self-orientalization' a prerequisite for their eventual EU accession. Prior scholarship still contains considerable lessons, therefore, on the impact of Europeanization processes on domestic political institutions, actors, and discourses.

All in all, the papers offer a set of narratives on what individual states in the Western Balkans have made of Europeanization over the past few decades: they clearly indicate how, across the region, the reference to European influence, rather than real European influence itself, has triggered some modest evolution in policy while leaving fundamental institutional change out in the cold. This special issue's main contribution, therefore, is to update past work with considerable empirical data from the Western Balkan countries on the flexibility of Europeanization's narratives. All the contributors make clear that whereas the process of Europeanization is never a clear-cut, seamless, continuous, andcrucially -irreversible, the narratives of Europeanization are flexible enough to present 'backsliding', 'hooliganism', and 'stalled Europeanization' as positive experiences that states make while 'learning from the West'.

Whereas from the point of view of Europe, Europeanization is mainly about state-building, political entrepreneurs systematically tailor their narratives of Europeanization to domestic expectations; in the Western Balkans, they have modelled state institutions on an image of a 'lean' if not an outright 'night watchman' state. Such states run greater risks of being hijacked by various powerful 
actors: the ethnic majority (as discussed by Anna-Lena Hoh), marginalized ethnic minorities (Laura Wise and Timofey Agarin), citizens concerned with issues of security (Nevena Nancheva), ardent and uncompromising nationbuilders (Michael Potter), uncommitted human rights agents (Niké Wentholt), and those committed to patronage by security forces (Anastasiia Kudlenko). All the papers implicitly state that state-building has been successful because it has been combined with the rationale of nation-state building, thus enabling the citizens of Western Balkan states to 'buy into' European concerns over the state's ability to serve competing constituencies, frequently framed in ethnic terms. Regrettably, all this fits excellently into the arguments of those Eurosceptics who have called for Brussels to repatriate powers to national capitals: a lean state, a lack of interstate solidarity, self-interested if not self-serving political elites, and public opinion riding the wave of short-term benefits but neglectful of the long-term impact of EU membership. 